\title{
The European Association for American Studies
}

announces its next international study conference to be held in the Villa Rigot of the University of Geneva (situated opposite the United Nations Palace), on April 27-29, 1972. The general theme of the conference will be:

The Impact of American Dissent on European Political, Social and Cultural Thought

\section{The Program}

26 Apr.

9 a.m., Meetings of the Executive Committe of the EAAS

3 p.m., 8 p.m. (Villa Rigot)

27 Apr.

$8.30-9.30$ Registration of participants

$9.30-9.45$ Welcome and Introduction

9.45-10.30 Lecture: American Influence on European Decolonization

10.30-10.45 Coffee break

10.45-11.45 Discussion

11.45-12.30 Lecture: Wilsonion Ideas and European Politics

15.30-16.30 Discussion of Dr. Spillmann's lecture

16.30-17.15 Lecture: The Impact of American Political Ideas in 18 th Century Italy

17.15-18.15 Discussion

28 Apr.

9.15-10.00 Lecture: American Dissent and the French Left

10.00-11.00 Discussion

11.00-11.15 Coffee break

11.15-12.00 Lecture: The American Impact on the German New Left

15.30-16.30 Discussion of Prof. Shell's lecture

16.30-17.15 Lecture: The Influence of American Dissent on the New Left in Dutch Political Lite

17.15-18.15 Discussion

29 Apr.

9.15-10.00 Lecture: The Influence of American Jewish Trade Unionism on Jewish Europe

10.00-10.15 Coffee break

10.15-11.15 Discussion

11.15-12.00 Lecture: The Intluence of Ezra Pound on European Poetry

12.00-13.00 Discussion

15.00-15.45 Lecture (?): American Feminism and Its Influence on the Emancipation of Women in Europe

15.45-16.45 Discussion (?)

16.45 Closing of the Conference
(Villa Rigot)

Prof. A. N. J. den Hollander, Univ. of Amsterdam (Chairman EAAS)

Dr. D. C. W Watt, London School of Economics

Dr. Kurt Spillmann, Univ. of Zürich

Prof. Vittorio Gabrieli, Univ. of Rome

Prof. S. Hurtig, Sorbonne

Prof. Kurt Shell, Univ. of Frankfort

Dr. R. Kroes, Univ, of Amsterdam

Dr. C. Abramsky, Univ. College, London

Prof. Chr. von Nagy, Univ. of Basel

Speaker? 